\title{
PERAN CITY BRANDING DAN EVENT PARIWISATA DALAM MENIGNKATKAN KUNJUNGAN WISATAWAN
}

\author{
Lailatus sa'diya, Nurita Andriani \\ Universitas Trunojoyo Madura
}

\begin{abstract}
The natural and cultural wealth of the regions in Indonesia has become a tourism potential to be developed in improving the country's economy. The implementation of regional autonomy has encouraged the government to further develop and market the advantages of the tourism sector, one of which is creating city branding. City branding can attract the attention of tourists to visit an area because the city can build a clear identity, strong associations, and embed positive attributes so as to win competition with other cities, especially in the tourism sector. Tourism events as tourist attractions serve as one of the strengths of the local government and the community to attract visiting tourists. City branding and events can create perceptions for visitors so that they can stimulate the decision to visit tourists to an area.
\end{abstract}

Keyword : city branding, tourism event, visiting decision.

\section{PENDAHUUAN}

Kekayaan alam dan budaya yang dimiliki daerah - daerah di Indonesia menjadi potensi pariwisata untuk di kembangkan dalam meningkatkan perekonomian negara. Pariwisata merupakan salah satu jenis industri yang mampu mendongkrak pertumbuhan ekonomi negara, membuka lapangan usaha baru, meningkatkan penghasilan, menaikkan standar hidup serta menstimulus sektor-sektor produktif lainnya.

Dijaman millenial ini industri pariwisata berkembang pesat, Setiap daerah berlomba-lomba menarik perhatian wisatawan dengan dengan berbagai kegiatan pemasaran yang dilakukan. Implementasi otonomi daerah telah mendorong pemerintah untuk semakin mengembangkan dan memasarkan keunggulan sektor wisata salah satunya dengan meciptakan merek kota (city branding). City branding dapat menarik perhatian wisatawan untuk berkunjung ke suatu daerah, hal inidkarenakancity branding dapat membentuk positioning dan diferensiasi dalam memasarkan suatu daerah sehingga sebuah kota dapat membangun identitas yang jelas, asosiasi yang kuat, dan menyematkan atribut positif agar mampu memenangkan persaingan dengan kota lainnya terutama dalam sektor pariwisata.

Sesuai apa yang dikatakan oleh (Kotler, 2000:18) mengenai unsur bauran pemasaran yang pertama yaitu product,produk dapat diartikan segala sesuatu berupa 
barang atau jasa yang dapat ditawarkan kedalam pasar untuk diperhatikan pembeli, diusahakan untuk dimiliki, dipakai atau dikonsumsi sehingga dapat memuaskan suatu keinginan atau kebutuhan konsumen. Sebuah produk yang hendak dipasarkan membutuhkan suatu Brand (merek). Menurut Kotler dan Keller (2009:258) merek merupakan sebuah nama, istilah, tanda, lambang atau desain dan kombinasinya yang dimaksud untuk mengidentifikasi barang atau jasa dari salah satu penjual dan mendiferensiasikan mereka dari pesaing. Dalam konteks ini, brand diaplikasikan untuk suatu daerah atau kota yang kemudian disebut city branding Merek Kota (City branding) adalah manajemen suatu destinasi melalui inovasi strategis serta koordinasi ekonomi, sosial, komersial, kultural dan peraturan pemerintah (Anholt dalam Moilanen dan Rainisto, 2009:7).

Selain merek kota (city branding), pemasaran pariwisata suatu daerah memerlukan daya tarik wisata salah satunya dengan adanya event. Event berfungsi sebagai salah satu kekuatan dari pemerintah daerah dan masyarakat untuk menarik para wisatawan berkunjung. City branding dan event dapat menciptakan persepsi pada pengunjung sehingga dapat menstimulus keputusan berkunjung wisatawan ke suatu daerah.

\section{Rumusan Masalah}

Bagaimana peran city branding dan eventpariwisata dalam peningkatan jumlah wisatawan?

\section{TINJAUAN PUSTAKA}

\section{Pemasaran Tempat (Place Marketing)}

Kotler dan Gertner (2002) mengatakan bahwa 'place' adalah negara bangsa, wilayah geopolitik, regional atau negara bagian, kebudayaan, sejarah atau etnik dalam batas wilayah yang sama, ibu kota dan populasi yang mengelilinya, pasar dengan variasi atribut yang dapat didefinisikan, pusat industri dan pengklusteran seperti industri dan supliernya, serta atribut psikologis yang dihasilkan dari hubungan manusia. Yananda dan Salamah (2014:19) mendefinisikan tempat sebagai budaya, politik, dan geografi secara pesat meningkat juga dilihat sebagai produk.

Menurut Kotler dalam Yananda dan Salamah(2014:16) Place Marketing adalah perancangan suatu tempat untuk memuaskan kebutuhan target pasar. Place marketing 
dapat dikatakan sukses jika warga kota dan pebisnis sangat senang dengan komunitasnya dan para pengunjung dan investor mendapatkan keinginannya.Pemasaran tempat adalah aspek dari pembangunan perkotaan (Urban Development).

Menurut Porter dalam Yananda dan Salamah (2014:16), kompetisi ekonomi global telah menyentuh persaingan di tingkat global. Karenanya pemasaran tempat dimanfaatkan untuk melakukan pembangunan perkotaan menghadapi globalisasi dan persaingan. Rainisto (2003: 26-28) menyatakan bahwa pemasaran tempat adalah aspek dari pembangunan suatu tempat. Menurut Yananda dan Salamah (2014:17) tiga komponen penting pemasaran daerah adalah penetapan positioning, pengembangan diferensiasi dan upaya membangun merek daerah. Positioning adalah upaya untuk membangun suatu psisi tertentu di benak pelanggan. Diferensiasi adalah upaya untuk membedakan diri melalui value proposition yang unik dan berbeda dari apa yang diberikan oleh daerah pesaing. Dan membangun merek tidak lain adalah membangun awareness, asosiasi merek, persepsi kualitas, dan loyalitas merek. Positionig yangtepat yang ditopang oleh diferensiasi yang kokoh dapat menghasilkan merek daerah yang kokoh dan kredibel di mata pelanggan. Daerah juga harus melakukan segmentasipasar dan secara fokus memilih pelanggannya. Selain itu menjalankan Marketing Mix (Product, Price, Place dan Promotion), strategi penjualan dan harus memperlancar proses di dalam organisasi da memperkuat layanan kepada pelanggan daerah (Kartajaya dan Yuswohady, 2005:13).

\section{Merek kota (City branding)}

Branding kota diterapkan oleh berbagai tempat di dunia salah satunya kota New York.City branding NewYork diinisiasi oleh kebangkrutan kota tersebut yang diperparah dengan penolakan pemerintah federal AS untuk memberi bantuan. Dengan melibatkan orang-orang ahli yang berkompetensi New York berhasil bangkit. Artinya, city branding adalah sebuah proses yang melibatkan bermacam orang dengan bermacam keahlian. Dengan penyatuan berbagai macam kemampuan tersebut menghasilkan logo "I Love New York"' yang sangat terkenal di seluruh dunia. Kota New York Konsisten dalam menerapkan brand yang merupakan proses kreatif untuk mencegah kerancuan dari produk sejenis yang dibuat oleh pihak yang berada diluar program (Yananda dan Salamah, 2014:141-146). 
Anholt dalam Moilanen dan Rainisto (2009:7) City branding adalah manajemen suatu destinasi melalui inovasi strategis serta koordinasi ekonomi, sosial, komersial, kultural dan peraturan pemerintah. Yananda dan Salamah (2014:34) menjelaskan bahwa city branding berfungsi sebagai alat untuk mengkomunikasikan tempat (kota, Kabupaten, atau provinsi) pada pemangku kepentingan. Sebuah kota dengan brand yang kuat mampu menjadi berbeda diantara kota lainnya. Melalui brand sebuah kota dapat berada di benak masyarakat ketika memikirkan sebuah tempat, artinya, city branding berperan dalam menciptakan postioning dan diferensiasi terhadap suatu kota sehingga mampu memenangkan persaingan antar daerah.

Proses branding merupakan paradigma baru terkait bagaimana tempat harus dikelola dimasa yang akan datang (Anholt, 2005). Namun berbeda dengan produk, sebuah kota merupakan entitas yang kompleks dan terkait dengan alam, orang, benda, dan lingkungan buatan. Kota merupakan kumpulan aktivitas yang dinamis yang meneydiakan barang dan jasa untuk individu, membentuk klaster ekonomi dan memungkinkan proses aglomerasi perkotaan (urban aglomeration) (Yananda dan Salamah, 2014:55).

Malik, Dkk (2016) mengatakan bahwa city brandingmerupakan identitas dari suatu wilayah yang memberikan kesan dan pesan tertentu terhadap seorang konsumen (wisatawan). Pakarti, Dkk (2017) menyatakan city branding adalah suatu strategi dengan cara memberi merek pada kota yang berfungsi sebagai alat untuk memperkenalkan atau memasarkan potensi daerah tersebut pada semua stakeholder dari lokal hingga internasional.

Dari beberapa penelitian diatas, dapat disimpulkan bahwa city branding adalah proses pemberian merek terhadap kota sebagai suatu strategi untuk memasarkan potensi suatu daerah pada seluruh pemangku kepentingan baik lokal maupun internasional. Salah satu tujuan city branding yaitu menarik perhatian wisatawan dan investor untuk membangun kota dan memasarkan potensi daerah.

Efektivitas aktivitas branding dapat diukur dengan city branding Hexagon (Yananda dan Salamah, 2014:69) yang terdiri dari:

1. Presence; yakni status dan kedudukan internasional yang dimiliki kota dan seberapa akrab orang dengan kota tersebut

2. Place(Kehadiran); aspek fisik dari kota, seberapa cantik dan menyenangkan atau sebaliknya kota tersebut 
3. Potential(Potensi); kesempatan yang ditawarkan oleh kota, misal aktivitas ekonomi dan pendidikan

4. Pulse(Daya Tarik); keberadaan gaya hidup perkotaan yang vibrant atau ketiadaannya, bagaimana kota menggairahkan

5. People(orang); populasi kota dalam hal keterbukaan dan kehangatan juga terkait dengan masalah keamanan kota

6. Prerequisites(prasyarat); kualitas hidup dasar yaitu standar dan harga akomodasi dan kelengkapan publik

\section{Event Pariwisata}

Dalam Simanjuntak, dkk (2018) Pengembangan sektor pariwisata melalui eventpariwisata seperti Banyuwangi Etnho Carnival, International Tour de Banyuwangi Ijen, Festival Gandrung Sewu, Festival NgopiSepuluhewu (sepuluhribu),dan sebagainya yang di lakukan oleh Kabupaten Banyuwangi berdampak positif dalam menciptakan rasa ketertarikan wisatawan dan terlihat dalam peningkatan kunjungan wisatawan ke Kabupaten Banyuwangi dari tahun 2013-2017.Menurut Pakarti, Dkk (2017) Event adalah suatu atraksi yang bisa berupa tradisi, olahraga, budaya, ritual agama, dan perayaan tertentu. Sedangkan menurut Simanjuntak, Dkk (2018) Event merupakan salah satu bagian dari daya tarik wisata yang memperlihatkan keindahan dan keunikan adat, budaya, kondisi geografi dan potensi yang dimiliki oleh daerah dan dipersiapkan dengan tujuan untuk dipertontonkan kepada masyarakat umum.

Menurut Çelik dan Çetinkaya (2013:15) event parwisata didefinisikan sebagai kegiatan perencanaan, pengembangan dan pemasaran yang mengembangkan sumber daya dan destinasi pariwisata alam dan fisik, membuat citra dan sebagai daya tarik wisata. Sedangkan Higgins (2017:74) menyatakan bahwa event pariwisata adalah perencanaan sistematis, pengembangan dan pemasaran event yang direncanakan sebagai tempat wisata dan untuk keuntungan mereka dalam memasarkan tempat, membentuk citra dan pengembangan.

Menurut Getz (2007:26) faktor-faktor yang berkontribusi dalam membuat event menjadi spesial yaitu uniqueness (unik) yang mencakup dari elemen gaya seperti, hospitality (keramah tamahan), symbolism (simbol), festive spirit (suasana meriah), theming (tema), dan authenticity (autentik). 


\section{Keputusan Berkunjung Wisatawan}

Arjana (2016:66) mendefinisikan wisatawan sebagai orang atau sekelompok orang yang melakukan perjalanan atau berwisata yang memiliki tujuan tertentu dalam melakukan perjalanan yang dilakukannya. Dalam konsep ini teori pengambilan keputusan berkunjung diambil dari teori pengambilan keputusan berkunjung konsumen.

Peter dan olson (2013:163) dalam Simanjuntak, dkk (2018) mendefinisikan pengambilan keputusan konsumen (wisatawan) sebagai proses integrasi yang digunakan untuk mengkombinasikan pengetahuan untuk mengevaluasi dua atau lebih perilaku alternatif dan memilih diantaranya. Pengambilan keputusan pembelian menurut Kotler dan Amstrong (Alma, 2013:104) terdiri atas tahap-tahap sebagai berikut:

1. Pengenalan Masalah

2. Pencarian infornasi Berbagai Alternatif Solusi,

3. Evaluasi Berbagai Alternatif Solusi

4. Keputusan Pembelian,

5. Penggunaan Pascapembelian dan Evaluasi Ulang Alternatif yang Dipilih.

\section{METODE PENELITIAN}

Penelitian ini menggunakan pendekatan fenomenologi Brouwer (1984:3) fenomenologi tidak bisa hilang dan menjadi syarat mutlak bagi seseorang yang mau memikirkan dasar dari usaha ilmiah atau dari hidupnya sendiri. Lebih jauh, fenomenologi mengajarkan kita untuk membiasakn diri melihat fenomena yang ada bukan lagi bendabenda.

Objek dalam penelitian ini merupakan studi kasus yang dilakukan terhadap kota yang menerapkan city branding dan event yang merupakan usaha dalam memasarkan daerah untuk menarik wisatawan berkunjung ke daerah tersebut. Menurut hegel, fenomenologi berkaitan dengan pengetahuan yang muncul dalam kesadaran, sains yang mendeskripsikan apa yang dipahami seseorang dalam kesadaran dan pengalaman.

\section{HASIL DAN PEMBAHASAN}

Pemberian merek terhadap kota (city branding) merupakan hal yang penting dalam menciptakan positioning dan diferensiasi potensi wisata suatu daerah kepada 
wisatawan.City branding merupakan strategi pemasaran yang dilakukan oleh sebuah kota yang memiliki tujuan untuk meningkatkan pertumbuhan kota, terutama di bidang ekonominya. City branding yang dimiliki oleh suatu kota ini juga memiliki peran untuk mempengaruhi seorang wisatawan untuk berkunjung ke suatu destinasi atau kota yang sudah di brandingkan.

Menurut Anholt dalam Moilanen dan Rainisto (2009:7) City branding adalah manajemen suatu destinasi melalui inovasi strategis serta koordinasi ekonomi, sosial, komersial, kultural dan peraturan pemerintah. Sedangkan menurutPakarti, Dkk (2017) menyatakan city branding adalah suatu strategi dengan cara memberi merek pada kota yang berfungsi sebagai alat untuk memperkenalkan atau memasarkan potensi daerah tersebut pada semua stakeholder dari lokal hingga internasional. Dengan adanya branding pada suatu kota yang didukung oleh apa yang ada di kota tersebut yang berupa tempat, keakraban terhadap suatu kota, penduduk yang ramah standar fasilitas publik yang memadai serta potensi wisata dan budaya yang menarik akan menumbuhkan keinginan seseorang untuk berkunjung ke Banyuwangi maupun di tempat wisata (jannah, dkk. 2014).

City Branding memberikan kontribusi dalam mempengaruhi seorang wisatawan mengambil keputusan untuk mengunjungi suatu tempat/ destinasi (Malik, dkk. 2016). Penelitian Pakarti (2017) mengungkapkan bahwa wisatawan domestik lebih memperhatikan tagline sebagai alat untuk mengenal sebuah kota dalam membentuk keputusan berkunjung.Keberhasilan suatu branding kota dapat diukur dengan city branding Hexagon Anholt dalam Yananda dan Salma (2014:69) yang terdiri dari: Presence (kehadiran), Place(tempat),Potential(potensi), Pulse (daya tarik), People (orang), Prerequisites (prasyarat).

Eventpariwisata sebagai alat promosidapat menumbuhkan rasa ketertarikan wisatawan untuk berkunjung dalam meningkatkan kunjungan ke suatu daerah. Seperti yang diungkapkan Çelik dan Çetinkaya (2013:15) event parwisata sebagai kegiatan perencanaan, pengembangan dan pemasaran yang mengembangkan sumber daya dan destinasi pariwisata alam dan fisik, membuat citra dan sebagai daya tarik wisata.

Event memiliki dampak atau pengaruh signifikan terhadap keputusan berkunjung serta membantu untuk meningkatkan popularitas kota (Getz, 2008:405). Penyelenggaraan event positif akan mempengaruhi keputusan berkunjung wisatawan begitupun sebaliknya. 
Peneitian Pakarti (2017) menemukan Kabupaten Banyuwangi mampu memanfaatakan event sebagai alat untukmempromosikan potensi wisatanya.

\section{KESIMPULAN DAN SARAN}

Dari penelitian diatas dapat dikatahui bahwa city brandingdapat menciptakan positioning dan diferensiasi potensi suatu daerah dalam mempengaruhi wistawan untuk berkunjung ke suatu kota atau destinasi wisata yang sudah di brandingkan. Eventpariwisata sebagai alat promosi dapat menumbuhkan rasa ketertarikan wisatawan untuk berkunjung dalam meningkatkan kunjungan ke suatu daerah.City branding dan event dapat menciptakan persepsi pada pengunjung sehingga dapat menstimulus keputusan berkunjung wisatawan ke suatu daerah.

\section{DAFTAR PUSTAKA}

Yananda, M Rahmat \& Ummi salamah (Ed.) 2014. Branding Tempat. Jakarta Selatan: Makna Informasi.

Kotler, Philip \&Keller, Kevin Lane. Tanpa tahun. Manajemen Pemasaran Jilid 2Edisi 13. Terjemahan oleh Bob Sabran. 2009. Jakarta : Penerbit Erlangga.

Kotler, Philip \& Keller, Kevin Lane. Tanpa tahun. Manajemen Pemasaran Jilid 1. Edisi 13. Terjemahan oleh Bob Sabran. 2009. Jakarta : Penerbit Erlangga.

Simanjuntak, Daniel Fransiscus, Dh, Ahmad Fauzi, \& Irawan, Ari.. 2018. "Pengaruh Event Pariwisata Terhadap Keputusan Berkunjung (Survei pada Wisatawan Domestik yang Berkunjung ke Event Pariwisata di Kabupaten Banyuwangi)",Jurnal Administrasi dan Bisnis (JAB),(Online),Vol. 61, No.3 2018. .

Moilanen, Teemu and Rainisto.2009.How to Brand nations, cities, and destinations, a planning book for place branding. USA: Palgrative Macmilan

Anholt, Simon. 2007. Competitif Identity: The New Brand Management for Natios, Cities, and Regions. USA: Palgrave Macmillan.

Malik, Moh. Ibrahim, Wilopo, \& M. Kholid Mawardi. 2016. "Pengaruh City branding "The Soul Of Madura" dan Motivasi Wisatawan terhadap Keputusa nBerkunjung Ke Kabupaten Sumenep". Jurnal Administasi Bisnis (JAB), (online), Vol.37 NO.1 2016.

Jannah, Bidriatul, Arifin, Zainul \& Andriani Kususmawati. Pengaruh City Branding dan City Image Terhadap keputusan Berkunjung ke Banyuwangi. Jurnal Administrasi Bisnis (JAB)|Vol. 17 No. 1

Pakarti, Swastika, Kusumawati, andriani, Mawardi, M. Kholid. 2017. "Pengaruh City branding dan Event Pariwisata terhadap Keputusan Berkunjung serta Dampaknya pada Minat Berkunjung Kembali Ke Kabupaten Banyuwangi".Jurnal Administrasi Bisnis (JAB), (online), Vol. 47 No.1 2017.

Kuswarno, Engkus. 2009. Fenomenologi Metode Penelitian Komunikasi: Fenomena Pengemis Kota Bandung. Bandung: Widya Padjajaran 